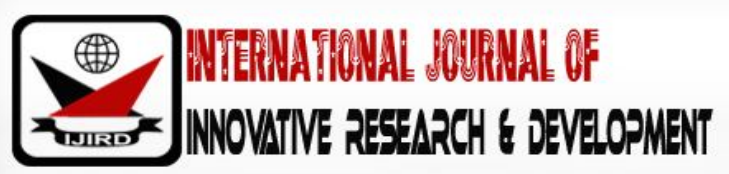

ISSN 2278 - 0211 (Online)

\section{Africa's Response to Global Terrorism: an Analysis of the Strengths and Weaknesses of Theories of Counter-Terrorism in Africa}

Anas Sani Anka
Assistant Lecturer, Department of History \& International Studies, Federal University Gusau, Nigeria

\begin{abstract}
:
This paper critically examines the strengths and weaknesses of the Africa's response to the global or International Terrorism. It makes a distinctive analysis of various theories of counter terrorism in Africa and how the theories can help in addressing terrorism in Nigeria. It also defined a clear attempt to coming up with a useful indigenous theory to address the excesses of Boko Haram Terrorism in Nigeria.
\end{abstract}

\section{Introduction}

One of the socio-economic and political crises that characterized the $21^{\text {st }}$ century Africa and its history is spread of insurgent activities across several states of the continent. This terrorist activity is believed to be harbored by series of sociopolitical and economic crises that range from system efficiency to failure of Africa's leadership institutions and new dimension of the democratization process that is affecting the continent in recent years. Many are of the views that, the democratization process and the leadership institutions it produced in Africa over the years have contributed to multiple number of social crises which pushes African citizens to committing all forms of social violence as a reaction toward seeking for redress. This negative development has however, become a threat to the survival of Africa as a continent especially that, there are forces that the citizens can leverage on to actualize the violence reaction. As argued by Cockayne (2011), illicit flows of money, arms and drugs are fueling the criminalization of politics and a growing kidnapping and ransom market which is in turn fueling Alqaeeda in the Islamic Maghreb,

Terrorism is defined as "an anxiety-inspiring method of repeated violent action, employed by semi-clandestine individual, group or state actors for idiosyncratic, criminal or political reasons whereby- in contrast to assassination the direct target of the violence are not the main target poverty, unemployment, corruption and resources marginalization had been considered as some of the reasons for the growing spates of insurgent groups in Africa Nations", United Nations (2009). Most of the terrorist groups in Africa hides under the pretence of religious, political, cultural and social factors to perpetrate their violent acts with sole aim of attracting public sympathy. The activities of the Yusufiyya movement otherwise known as known as Boko Haram members in Nigeria for instance, have come to the public prominence when members of the group were massively arrested and their leader Muhammad Yusuf killed by the Nigerian police in Maiduguri in 2009 in what many Nigerians termed as "extra-judicial killing". Though not all Nigerians are in support of their reasons for going violent against the Nigerian state, the agitation by the international human right organizations and western media organizations after the killing of Muhammad Yusuf has helped in attracting them public sympathy especially by having more Nigerians of their like minds who are willing to join them to continue with the violence act. This has actually culminated to the present state of uncertainty which the group has caused the country. The Nigeria's Boko Haram sect constitutes a big threat to the nation's quest for sustainable development because of the factors that were born out of the deliberate failure of the Nigeria's government to handle. They have succeeded in making their campaign against the state very popular because of the enabling environment created by the failure of the Nigeria's leadership institution. Collier and Hoeffler (2004) argued, the cost of organizing rebellion is lower where there is large youth population (which is relatively cheap to recruit), where there are high level of poverty and illiteracy or where there is an abundance of easily lootable resources.

Terrorism and terrorist's activities have caused heavy damage to the socio-economic and political stability of Africa. From Alqaeeda in the Islamic Maghreb to Al-shabab Militia in Somalia and Boko Haram insurgency in Nigeria, terrorism has probe to be one of the cheapest violent means through which Africans used to express their anger against the states. These terrorist's activity which usually started as a local problem usually escalated to affect other neighboring states as well as connection with other striking terrorist groups who are in to similar mission. Like the case of Boko Haram in Nigeria, researches have shown that the group is connected to many international terrorist organizations that provided materials and human resource support including training for them. Omale (2013) argued, Boko Haram appears to have link to international terror organizations in Somalia, North Africa and Alqaeeda terror group. 
One most challenging perception of the concept of terrorism is that, Africans especially the elites and academics have failed to illustrate clearly whether Terrorism is a crime or a conflict. The western perception has however portrayed terrorism as a crime against the state. But using the theory of frustration and aggression the action may not really be a crime but rather a conflict especially looking at the under-development parameters in Africa.

Despite the challenges these terrorist groups poised to the continent, series of measures have been put in place by various governments in Africa to content their activities through containment, de-radicalization, rehabilitation, reconstruction and building of inter-states and agency synergy. These initiatives are considered best in reacting against counter-insurgency. Pimbo (2007) used the four "Ds" to best described the pastiest way of countering terrorism: Defeat terrorists and their Organizations: Deny sponsorship, support and sanctuary to terrorists: Diminish the underlying conditions that terrorists seek to exploit and Defend citizens and interest at home and abroad.

So many theories have been developed by scholars on how best to ensure a successful counter insurgency and one of them is Meghalaya theory. This theory is a multi-sector approach involving government, law enforcement, judiciary and civil society organizations that create a comprehensive framework for combating trafficking in North-East Asia in 1999 under the five "Ps" Prevention, Protection, Policing, Press and Prosecution (Kharbhih 2010). One of the objectives of this paper is to make an analysis of the theories of counter terrorism and see how relevant they are in containing insurgents and their activities in Africa.

\section{Definition of the Term "Terrorism"}

There is no globally accepted definition of Terrorism, each definition advanced by an intellectual represent an interpretation of the dynamics and dynamism of a particular violence that engulf a section of society or community where he understands better. But for the purpose of global perception, United Nations define terrorism as an anxiety inspiring method of repeated violence action employed by (semi) clandestine individual, group or state actors for idiosyncratic, criminal or political reasons whereby in contrast to assassination the direct targets of the of the violence are not the main targets. (United Nations. 1999). For the United States Department of Defense (USDD) terrorism, connotes a calculated use of unlawful violence or threat to inculcate fear: intended to coerce or intimidate governments or societies in the pursuit of goals that are generally political, religious or ideological. Within this definition there are three key elements - violence, fear and intimidation and each element produce terror in its victims. Omale (2013). For the US Department of States (USDS), terrorism could simply be defined as premeditated politically motivated violence perpetrated against non-combatants targets by sub-national groups or clandestine agents, usually intended to influence an audience Omale (2013). For International Terrorism and Security Research (ITSR) terrorism is a political and criminal act that influences an audience beyond the immediate victim and that the strategy of terrorists is to commit an act of violence that draws the attention of the local populace, the government and the world to their cause Omale (2013).

\section{Global Terrorism: An Over-view}

Africa since 1960s has been bedeviled by multiple number of internal crises which metamorphoses over the times in to what is termed as an act of "Insurgency" or "Terrorism". This development over the years has however, attracted transboundary attention to the extent that, terrorism is being carried out in a coordinated manner that calls for Africa's collaboration to contain it through what experts termed as "counter-terrorism strategy". As argued by James and Jennifer (2011), Africa has its own peculiar domestic collection of ideologically-inspired violent non-state groups that are responsible for periodic bouts of murderous mayhem. Some of these, like the Lord's Resistance Army in Uganda, al-Shabaab in Somalia or Al-Qaeda in the Islamic Maghreb in North Africa, have attracted ample media attention. Terrorism and Insurgency had been with Africa since during the post independent period. Many aggrieved person(s) who started violent fight against their respective governments in Africa today had created a new history that give a fresh definition to meaning and features of the continent. These armed group fighters all over Africa as argued by E. W (2014), takes advantage of instability and porous borders to further afield throughout the Sahel region.

There are many terrorist groups in Africa and both of them very popular in their own course but two are the most prominent with an International ranking by the United Nations. As argued by E. W (2014), Two African insurgencies now rank among the most dangerous internationally: Boko Haram in Nigeria and Somalia's al-Shabab. Going by the number of fatalities per attack, Nigeria now has the world's deadliest insurgency (killing an average 24 people per assault. In Egypt it is also not different because since the ouster of President Khosni Mubarak it has been violent reaction against every regime in Egypt. Egypt's popular revolt also left a legacy of extremism. A handful of Islamist groups have announced themselves in the Sinai since President Hosni Mubarak was ousted in 2011. But the scope of attacks increased after Egypt's military booted out the country's subsequent president E. W (2014), in Kenya it was also an uprising that makes the country not secured as argued by E. W (2014), Kenya has been particularly hard hit. Since the bloody siege on Westgate Mall in Nairobi, the capital, last year, a series of coastal attacks has cost hundreds of lives and hammered the tourism industry. The Nigeria's Boko Haram insurgency which reaches its peak level in 2009 with the brutal murder of its leader Muhammad Yusuf by the Nigeria's security agencies. The impacts of their activities extended to the neighboring Niger, Chad and Cameroun, the same thing with the Al-Shabab in Somalia. As argued by E. W (2014), Violence has split into neighboring Chad, Cameroon and Niger. In Somalia, al-Shabab has come under pressure from regional African forces, but has responded by striking beyond its borders. Apart from the notorious 
actions of the Alqaeeda in the Islamic Maghreb (AQIM) other groups splinted out in support of Gaddafi after his ouster. Other groups have spun out of AQIM, including the militia that claimed responsibility for seizing in an international gas facility in Algeria last year. Those groups have led grim credence to Qaddafi's prophecy that if he was toppled, North Africa would descend into holy warfare. "Bin Laden's people would come to impose ransoms by land and sea," he said as his rule became increasingly precarious.

Apart from the violent manners in which some African citizens reacts to states policies, there had been a perspective that some African leaders contribute to the increasing spates of terrorism and violence acts as they implore the use of force to crackdown on the opposition and activists criticizing their regimes, James and Jennifer (2011), argued, in addition to terrorist groups, there are also irresponsible governments that have employed the tactics of terrorism in (for example) a brutal crackdown against opposition leaders in Zimbabwe, or the Eritrean government's support (according to a recent UN report) for terrorist plots against African leaders gathering in Ethiopia. Many African leaders have been arraigned before the International Criminal Court among them is Omar Al-Bashir of Sudan and couple of others. James and Jennifer (2011), President Omar al-Bashir of Sudan is the first sitting head of state to be indicted by the International Criminal Court for crimes against humanity, while in the newly independent South Sudan, locals are calling for a war crimes investigation. In Senegal, riots erupted in the streets to protest President Abdoulaye Wade's attempt to change the constitution in an effort to be elected to another term in office. Add to that the tragic episodes of genocide in places like Rwanda and the Darfur region of Sudan and you have a first glimpse of the atrocities that the present African generation has witnessed.

Coming down to Nigeria Obene (2012) argued, Nigeria has remained relatively peaceful and terror free country between 1967-1970 until the killing of Dele Giwa by a "Letter Bomb" in October 1986. The annulment of the election of MKO Abiola in June 1993 has helped in raising another form of militia through the platform of Movement for the Advancement of Democracy. The Niger Delta Militancy and now Boko Haram, Nigeria have recorded scores of violence against the state by its citizens. These violent acts had led to hundreds of losses as summarized by Omale below:

\begin{tabular}{|c|c|c|}
\hline S/ NO & Incidences & Years \\
\hline 1 & General Secretarian Violence in Jos & 2004,2010 and 2011 \\
\hline 2 & Bombing and Killings in Maiduguri & 2004 -date \\
\hline 3 & New Year Eve Bombing of Mogadishu Military Cantonment Mammy Market Abuja & 2010 \\
\hline 4 & Presidential Inauguration Bombing in Anuja & 2010 \\
\hline 5 & October 1st Bombing in Abuja & 2011 \\
\hline 6 & Mammy Market Bombing in Bauchi and Zuba near Abuja & 2011 \\
\hline 7 & Post-Presidential 2011 Election in Northern Nigeria & 2011 \\
\hline 8 & April 8th Suleja INEC Bombing & 2011 \\
\hline 9 & Bombing of UN House & 2011 \\
\hline 10 & Bombing of Social Drinking Units in Maiduguri and Zuba and outskirt of Abuja & 2011 \\
\hline 11 & Bombing of Nigerian Police Force Headquarters & 2011 \\
\hline 12 & Bombing of Army Task Force Operational / Military formations in Yobe and Maiduguri & 2011 \\
\hline 13 & Bombing of St Theresa Catholic Church in Madalla near Abuja & 2012 \\
\hline 14 & Mubi, Yola, Gombe and Maiduguri Bombing & 2012 \\
\hline 15 & Kano Bombing & 2012 \\
\hline 16 & HQ 1Division Nigerian Army and Kawo Bridge Bombing in Kaduna & \\
\hline
\end{tabular}

Table 1: Summary of some Violent Acts by Terrorist Groups in Nigeria

Source: Omale (2013)

\section{Some Selected Theories of Terrorism}

There are several theories developed by scholars that seek to define the perspective and dimension of terrorism in Africa. These theories represent the peculiarity and dimension of each violence act as it affects a particular state.

\section{Greed or Opportunity Theory}

This theory precisely assumed that, citizens choose to joint terrorism due to its easy money-making nature. According to this theory, citizens prefer to join terrorism because it easy to get rich especially looking at the caliber of personalities that sponsored the terrorists and their activities behind the close door. Urdal, (2007) argued, rebellion is only feasible when the opportunity and potential gain from joining an armed group outweigh the benefit of not fighting and pursuing an alternative income-generation opportunity.

\subsection{Grievance Theory}

Many scholars have been able to establish strong connection between inequality and possible resistance or violence from the citizens especially from those who feels marginalized. According to Walton (2010), he sees armed violence as a response to relative deprivation or exclusion. There is no iota of doubt that, one of the factors that pushed Nigerian youths to joining insurgent groups may not be unconnected with the bad feelings over deliberate political exclusion, poverty, 
unemployment and lack of secured environment that would promote economic stability and social sustainable development. Omale (2012) argued that, many people in Nigeria call for the restorative justice paradigm because they are "aggrieved and hurt" socially, politically and economically and could not explain why people who stand in plenty of water should wash their hands with spittle. The theory also argued that, political awareness among African citizens especially the youths who feels politically marginalized. Omale (2012) argued, unlike Uganda where 19-year-old girl won election in to the National Parliament in 2012, section 65 ss (a) and (b) of the 1999 Constitution of the Federal Republic of Nigeria states otherwise that, "a person shall be qualified for election to the National Assembly if he has attained the ages of thirty-five years (for the Senate) and thirty years for the (House of Representative).

\subsection{Psychological Theory}

There is this common belief that, youths naturally are prone to violence and that they are the cheapest means that can be employed or engage to perpetrate some violence acts. As argued by Walton (2010) adolescents may be more susceptible to recruitment by rebel groups or to engage in violence for a number of psychological reasons, emotional development or identity construction. The high rates of poverty and unemployment are strongly connected to this analysis because when youths who are supposed to be academically sound and who are fit enough to contribute to nation building are abandoned by the political class and other powers that be, there is every tendency that they may be prone to violent engagement especially to those that are willing to finance him for their selfish gain.

\subsection{Social and Political Exclusion Theory}

This emphasized on the wider gap that existed between the young people and their successful transition to adulthood. This analysis is made more strongly realistic in the context of conflict dominated areas. Hilker and Fraser (2000) argued, there is growing sense in the literature that, the social and economic statuses required for adulthood are increasingly unattainable for young people. Why is this situation? Walton (2010) argued, a number of ethnographic studies of young people in a number of different conflict-affected countries have identified various social, economic and political barriers that blocked young people's transition to adulthood and highlighted the central role these barriers can play in driving violent conflicts. This theory specifically blamed political elites in Africa as responsible for this development. The fact that, this political class who are majorly the minorities control their respective states resources, their continued marginalization of the resources through tactical wait-hood imposed on the youth necessitated certain forms of reaction that resulted to violence and insurgency. Yousuf (2003) argued, the fact that, resources are controlled by entrenched elites rather than poverty and inequality per se is what drive youth's grievance in recent times. So, taking of arms against the state or the political elite in these contexts can provide a means through which they can be integrated in to the society (by fire or by force) or gain the sense of purpose of recognition deny them by the society.

\subsection{Counter-Terrorism: Definitions and Theories}

Counter-terrorism connotes an approach or strategy adopted to manage an act of terrorism. Or in other ways, it may mean, an ability and willingness of the government and its people to manage or prevent an act of terrorism through multifactors approach. According to Free Dictionary.com terrorism means, operations that include the offensive measures taken to prevent, deter, preempt, and respond to terrorism. According to Barry K (2014), Counter-terrorism means, the practices, tactics, techniques, and strategies that governments, militaries, police departments and corporations adopt in response to terrorist threats and/ or acts, both real and imputed. The objectives of counter terrorism include among others: making citizens safer, disempowerment of the actors, building peace in society and re-integration of the terrorists in to the socioeconomic and political center. Since September 11 Attack, various multi-factors approach has been applied to contain insurgents and their activities. Many people ask how does counter terrorism worked? Barry K (2014), states, there are two aspects of counterterrorism. The first is to make citizens safer from terrorist threats through screening of airline passengers, placing video cameras and metal detectors in public places, random patrols of bomb-sniffing dogs, etc. The second is neutralization of terrorists through arrests, prosecutions, assassinations, raids on terrorist facilities, military action, etc.

States in Africa have made efforts to adopt one forms of counter terrorism or the other especially in collaboration with other neighboring states who are directly or indirectly affected by this acts terrorism. These approaches to some extent have assisted in managing insurgent activities to a reasonable extent. Notwithstanding however, from the academic points of views, the best way to understanding the concept of counter terrorism and how it works is by analyzing some existing theories which tends to define stages and function of the processes of counter terrorism.

\subsection{Regime Theory}

This theory emerged in the late 70s and early 90s and its approach deals with international environmental and economic cooperation. To the proponents of this theory, counter-terrorism is not a monolithic field and it is analytically useful. They believed that, externality factor is key and that understanding the strategies adopted in an environment outside your territory enables you to adopt other options that will help you manage insurgency in your own internal environment. Anagnostaki (2012) argued, that for the purpose of examining multilateral counter-terrorism cooperation to distinguish between the various sub-component of counter-terrorism instead of treating the later as unified and solid issue area. 
They see collaboration between states to contain insurgency as the best approach especially that, not even the United States is able to provide to the entire nations a single and all-encompassing strategy to fighting terrorism. To the advocates of regime theory, globally and regionally, the existing institutional arrangements for the fight against terrorism do not cover the whole spectrum of counter-terrorism tools and instruments. In other words, an overarching all-encompassing counterterrorism regime does not exist and a piece meal approach is followed where pattern of cooperation emerged only in specific sector Anagnostaki (2012).

They also advocated that, there is need to have a clear synergy between the internal security approaches and their relationship with the external environment. Internal security measures in fighting corruption alone cannot lead a nation to manage insurgency without identifying external opportunities and tapped on them, in other words, you need the external environment potentials to succeed in the counter-terrorism fight because the two factors are interwoven. As argued by Anagnostaki (2012), internal security including elements that are relevant to counter terrorism has external aspects and that the highly trans-national character of International terrorism poses several challenges to states. Terrorism has emerged as trans-boundary security issue of pressing concern especially after the September 11 attacks. To the advocates of this theory, national policies on security are sound enough to provide the headway but they cannot alone lead to successful counterinsurgency. Trans-national counter terrorism cannot be fought through purely national measures and various national counter-terrorism policies are to some extent linked together Anagnostaki (2012).

What the proponents of this theory are saying in essence is that, every act of terrorism is accompanied by an act of negative externalities and that the impacts of an act of terrorist act like Boko Haram for instance has a negative consequence on the neighboring Niger, Chad and Cameroun and the best way to successfully tackle it is by synergizing with these neighboring states to define some unique security measures. Anagnostaki. (2012), argued, trans-boundary externalities occur when the action that took place in the jurisdiction of one state have a direct impact on and affect the welfare of other states. These impacts may be tangible or intangible and the create the need for international environmental cooperation and for the establishment of a governance system.

\subsection{The Meghalaya Theory}

This theory is a multi-sector approach developed by stakeholders including government, law enforcement agencies, judiciary and civil society organizations to create a comprehensive blue print for combating trafficking in North-East Asia in 1999 using the five "PS". The five Ps under this theory represent Prevention, Protection, Policing, Press, and Prosecution. Omale (2013) argued, Meghalaya model is designed to track and rescue trafficked children in North-East Asia: to facilitate rehabilitation and making sure that, survivors do not get re-trafficked. It also provides families with livelihood alternatives; provide evidence to prosecute offenders and raises awareness through the media. The Meghalaya theory adopted a simplest process of using five "RS" this include: Reporting, Rescue, Rehabilitation, Repatriation and Re-education Omale (2013). Though one may wonder how a theory that is design to manage human trafficking can be useful to counter-terrorism and this is possible in the argument of Omale (2013), these activities that are pillars of the Meghalaya model to counter human trafficking are relevant to counter-terrorism as they could fight the supply of the terrorists, supply of the mercenaries for terrorism and demand for the terrorist's network. Looking at the nature of Boko Haram terrorism for instance some of the factors that influence their successful operation is the porous nature of the Nigeria's borders which make it easier to trafficked people from the neighboring states of Niger, Cameroun and Chad as well supply weapons in to the country for their continued violence against the state and its people and the porous borders again supported their ability to operate as network this model of Meghalaya can best be adopted by Nigeria and several state that battling with insurgencies in Africa. As argued by Omale (2013), this model is relevant to counter terrorism in Nigeria because through a collaborative and far-reaching security network of stakeholders in counter terrorism and human trafficking (Security and Intelligence Agencies, NAPTIP, the Media, Civil Society and NGO's), terrorist's mercenaries and terror suspects are more likely to be arrested and will face prosecution.

\subsection{CTPPP Theory}

This theory is closely related to the Meghalaya theory and it is all about Countering Terrorism through Public Private Partnership (CTPPP) and this has to do with the opening of window of partnership and collaboration with the Private sectors to support counter-terrorism fight through human resource development and expertise. Global Counter-Terrorism Strategy explicitly encourages such partnership in capacity building and information exchange. Hence the United Nations Counterterrorism Implementation Task Force (CTITF) working group on countering the use of internet for terrorist's purposes argues how it benefited from private sector expertise in the technical and legal aspect on how the internet could be used to counter terrorist's narratives (Omale 2013). This development has been tasted by some developed countries and it has yielded positive result. The roles of private partners under this theory should not be limited to that of business alone but rather it can be extended to that of counter terrorism. In the views of Yudintsev, (2012), private-public cooperation should not be limited to the business community alone but should also include non-governmental organizations, media, tourism and hotels, youth's associations, academic community and religious leader's involvement in security sectors. 


\subsection{Women Gender Intelligence Theory}

This particular theory considered women as critical to counter-terrorism management in Africa. In Nigeria for instance, women have been considered critical resources for terrorism and terrorists activities. From Maiduguri to Yobe, Adamawa, Jos and Kano, women had been used as critical instruments of violence against the state. The advocates of this theory are strongly of the opinion that, African women need to be sensitized on the dangers of selling themselves cheaply to violence and violent act. Their potentials as mothers and symbols of parenthood need to be strengthen so that, they can stay away from violence as argued by Omale (2013), for instance with the continued violent conflict in Jos and emerging suicide bombings in the country, the "Women for Change and Development Initiative" of the office of first lady of Nigeria orchestrated media campaigns and jingles of "Women see something: Say Something" the one that give life must protect life.

There are several other theories that seeks to define counter-terrorism from other experience of the African countries which all formed parts of the measures taken to wipe away insurgency in the continent. These theories include

\section{Counter-terrorism through the "Theory of New Dimension"}

This a theory develops in the course of this research considering the in effectiveness of some of the perceptions in the existing theories reviewed in this work. My concern about the regime theory for instance is that, though they emphasized on the need for collaboration between the victim state and external environment as the best approach to collaborate in fighting insurgency, I argued in the contrary that, most collaborations in this perspective failed because of three main factors, national interest, diplomatic rivalry and isolation from the ownership of the actual problem. Several times, government of Niger, Chad and Cameroun for instance, considered Boko Haram insurgency as purely Nigeria's problem and this is why they always tend to be reluctant in fulfilling their own obligation of strengthening more synergy to end the Boko Haram crises. Except in the area of joint military operation not much had been done in a collaborative means to end the Boko Haram menace. The issue of national interest of the victim states is also one of the weaknesses of the trans-boundary collaboration in the counterterrorism. Sometimes there are cases where neighboring states supported the insurgent groups through armed supply, financial support and other aids. Libya for instance is considered critical to the survival of Boko Haram insurgency because most of the arms and other dangerous weapons allegedly get to these people through Libyan border. On the women gender theory also, I found their argument as lacking in substance because, they did not provide alternative strategies to resolving series of social and economic crises confronting African women. From maternal mortality crises to poverty and illiteracy, African women have been subjected to unending social and economic crises that left them with no option than to resort to violence means and sometimes make themselves as cheap products for interested insurgents. The awareness and sensitization of women through jingles and media outlets the proponents of this theory considered significant are not enough because majority of the Nigerian women who opted to go violent knows fully that it was not the best option but the hard condition of living in Africa pushed them in to that inhuman act.

My theory of New Dimension was however, framed around the use offour "Cs" referring to Change in the government Approach to governance, Commitment to Act by making the change very visible, Collaboration to Raise Awareness on Changes and Congregation to Conducting time-to-time Appraisal. In my own analysis of the how the four "Cs" work in counter insurgency in Africa, I agree with some schools of thought that, many insurgents took to violence in reaction to government approach to issues of economy, politics and social development, these are actually the push factors. the economy did not in any way favour the low-class citizen, there is exclusion of the majority in the political arrangement as well as imposition of unfavourable social conditions such as poverty, unemployment, diseases and social crises. This characterization is a real invitation to violence and vulnerable citizens have tendency of reacting to this governance approach which is akin to most African states. Change in the government approach this is one of the most effective non-cohesive measure that can help in ensuring effective containment of the citizen's reactions.

Commitment to act in this theory connotes two things, number one the real political will from the government and all the security stakeholders to contain the insurgents through cohesive means as well as remove all barriers to inter-agency performance. Secondly, the government needs to commit to its citizens by implementing the new leadership approach which will help reverse the old terrain of socio-economic and political barriers against the majority.

Collaboration to raise awareness is not limited to propaganda on the success of the war against terrorism but the existence of the new approach that seeks to address such class in-balance that existed between the aggrieved citizens and those that represent the political class. Such awareness shall be devoid of sensationalism. Importance of peace, national unity and availability of space for political inclusion shall be given emphasis.

The last is congregation to conducting appraisal; this is basically the problem with governance in Africa. Most African leaders do not take time to appraise the efficiency of their policies and programme. Looking at the Nigerian perspective for instance, the social problems that bedeviled the North-Eastern Nigeria is not really with the government policies as they affect the region but lack of consciousness to appraise them and identify the existing gaps. Every month for instance, allocation goes to all the states in the region but poverty and unemployment are always at increase and this may not be unconnected with government lack of concern to follow up policy implementation as they affect citizens as well as fight corruption. 


\section{Conclusion}

From the discussion so far, it is very clear that, terrorism and insurgency is caused as a result of citizens violent reaction to certain decisions, policies and programmes of the political class and that, change of approach alone can serve as the best counter-way to manage and curtail violence from the citizens. This social and economic factor that pushes Africans to violence are the most common characteristics of the continent and its people. Therefore, beyond western theories of counterterrorism, Africans hold solutions to their hand simply by changing in the approach.

\section{References}

i. Anagnostaki, D, (2012), Regime Theory and Global Counter-Terrorism: Some Starting Points,

ii. Cockayne, J (2011), State Fragility, Organized Crime and Peace Building: Towards a More Strategic Approach, Norwegian Peace Building Resource Center, NOREF Report.

iii. Collier, P, and Hoeffler, A. (2004) Greed and Grievance in Civil War, (Online Version) Oxford Economic Papers 56(4) 563-595 retrieved from http:/ / bit/ ly/ eRJIpu.

iv. E. W (2014), Africa's Deadly Insurgencies: Ranking High on the Wrong Measures, (Online Version) Baobab retrieved from www.economist.com 19th March 2017

v. Hilker. L \& Fraser. E (2009), Youth Exclusion, Violence, Conflicts and Fragile States (Online Version) Report Prepared for DFID's equity and rights team, Social Development Direct. Retrieved from http:/ / bit.ly/ c9vu4c 23 March 2017

vi. James J.F. and Jennifer (2011), Terrorism and Political Violence in Africa: Contemporary Trends in a Shifting Terrain, (Online Version), Terrorism Research Initiative, Vol 5(1).

vii. Obene. W. R. (2012), Home-grown Terrorism: An Emerging Challenge to Nigeria's National Security, Presentation to Haske Biyu 2012 Participants at the Armed Forces Command and Staff College, Jaji Kaduna, 03/ 04/ 2012.

viii. Omale, D. J. O (2012) Restorative Justice and Victimology: Euro-Africa perspective, (Online Version) The Hague Publishers, retrieved from www.wolfpublishers.com/ book

ix. Piombo J R (2007), Terrorism and Counter-terrorism Programmes in Africa: An Over-view, Strategic Insight 6(1)

x. UN, (2009), United Nations Policy for Post-Conflict Employment Creation, Income Generation and Re-integration, (Online Version), United Nations Geneva, retrieved from http:/ / bit.ly/ bN4K65

xi. Walton. O. (2010), Youth, Arm Violence and Job Creation Programmes: A Rapid Mapping Study, (Online Version), Norwegian Peace Building Resource Center (NOREF).http:/ / www,gsdrc.org/ docs/ open.EIRS11,pdf

xii. Yousuf. T. (2003), Youth in the Middle East and North Africa: Demography, employment and Conflict. In Ruble et. A.I (Eds) Youth Explosion in Developing World Cities: Approach to Reducing Poverty and Conflicts in Urban age, (Online Version) Woodro Wilson Centerhttp:/ / bit.ly/ 9ogRuF 